\title{
Hábitat Kawésqar: \\ Proyecto de Título como Investigación Proyectual
}

\author{
Claudio Pulgar P. / Profesor Guía: Gustavo Munizaga
}

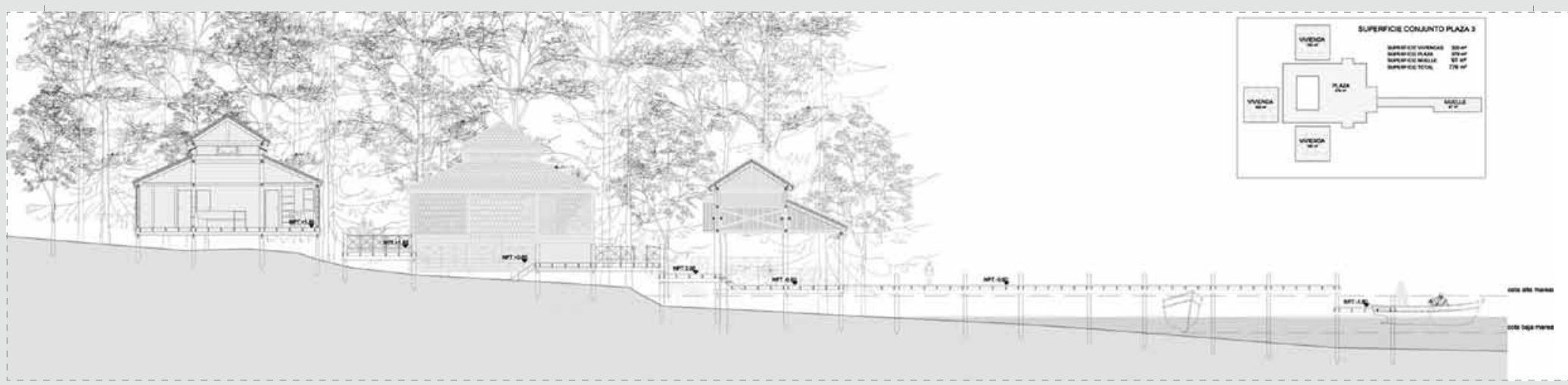

El proyecto de título se concentra en la comunidad indígena Kawésqar actual, en peligro de extinción, de los cuales sólo 22 personas (lo que representa sólo 8 familias nucleares) viven hoy en la aislada localidad de Puerto Edén, Región de Magallanes, Chile. Junto a ellos se desarrolló una investigación y luego una propuesta, para lo cual se viajó a terreno, con la idea de realizar un proyecto de arquitectura para y con ellos, que naciera de sus necesidades, inquietudes y anhelos. Se realizó un trabajo participativo, primero para realizar un diagnóstico de las necesidades y definir que proyecto hacer juntos, y segundo para diseñar y localizar la propuesta. Ésta se localiza en el archipiélago patagónico sur, frente a campo de hielos patagónico sur, en la única localidad poblada de todo el archipiélago.

El proyecto, que consiste en un traslado planteado por la propia comunidad a los terrenos de Jetarkte, dentro de la misma localidad de Puerto Edén, es una plataforma de desarrollo bajo el enfoque de la identidad, más pertinente y acorde con los pueblos indígenas. Un desarrollo no basado sólo en la satisfacción de necesidades o en la sobrevivencia a la pobreza, sino en el ejercicio de derechos y el bienestar plenos que permitan economías sostenibles interculturales (manteniendo rasgos de la economía de subsistencia, pero tomando en cuenta y explotando ellos mismos las nuevas oportunidades que presenta el turismo ecológico-cultural y responsable).

En la propuesta se entiende la vivienda como parte de un sistema mayor, no sólo como la unidad que acoge una familia, el hogar, sino también como parte de un sistema donde se incluye el entorno, el espacio público, el equipamiento, la infraestructura, el terreno, la urbanización; localizándose en un contexto mayor que involucra aspectos culturales, socioeconómicos, políticos y físico-ambientales; y además se manifiesta en distintas escalas y lugares, como en el caso del proyecto la localización rural, el barrio, el conjunto habitacional, los espacios públicos y finalmente las unidades de vivienda.

Desde esta visión sistémica del hábitat y de la vivienda en definitiva, se puede entender de mejor manera la propuesta a partir de sus distintas escalas (macroescala: el barrio Kawésqar de Jetarkte; mesoescala: el vecindario-clan familiar; microescala: la unidad de vivienda). Es importante destacar que el nuevo barrio Kawésqar de Jetarkte, se ubica en el borde costero del terreno perteneciente a la comunidad, funcionando como acceso y zona de amortiguación del Etnoparque Kawésqar planteado en la propuesta para conservar la diversidad biocultural y aprovechar turísticamente los terrenos de la comunidad Kawésqar. Por la complejidad de aspectos involucrados se planteó la propuesta como Hábitat Kawésqar, y no como una mera «solución habitacional». 

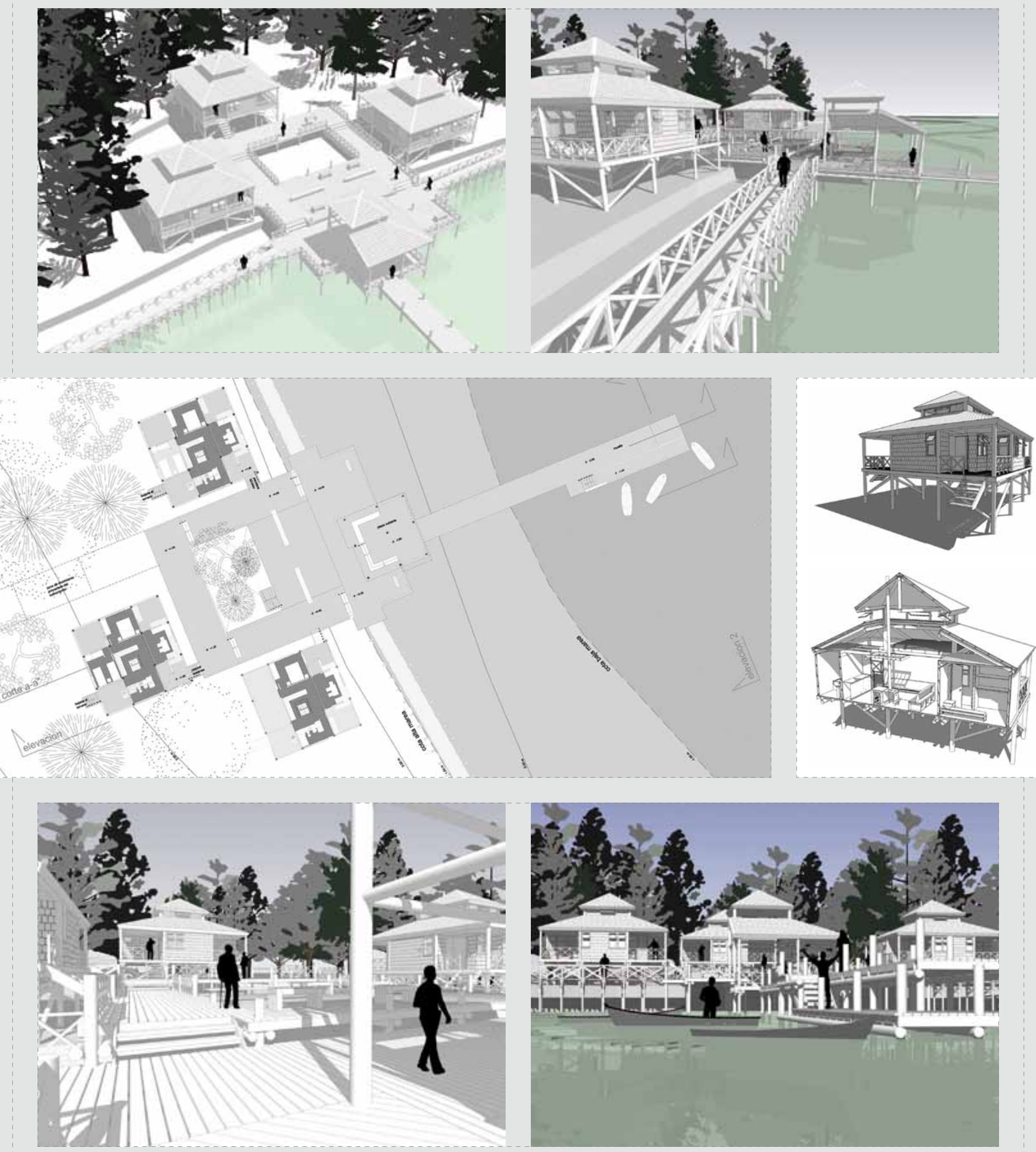